interested in aviation. His first models, like the oldfashioned quadrilateral boy's kite, had aëroplanes of considerable longitudinal dimensions, but on becoming acquainted with the gliding experiments of Chanute, Herring, and the Wright Brothers, he was not long in adopting the two-surfaced rectangular type. Captain Ferber materially developed our theories of longitudinal stability, and he also gave a mathematical investigation, probably the first, of lateral stability. In view of the last statement, and the fact that Ferber's machines were furnished with special triangular sails

\section{THE ROYAL OBSERVATORY AND} ELECTRIC TRAMWAYS.

F ROM statements recently appearing in the public Press, many people have been led to regard the Astronomer Royal as an uncompromising opponent of tramway electrification; but as it is perfectly well known that Greenwich is very well supplied with electric trams, it must be quite evident that this impression cannot be correct.

It is specifically alleged that:- -

(I) The extension of the overhead trolley system

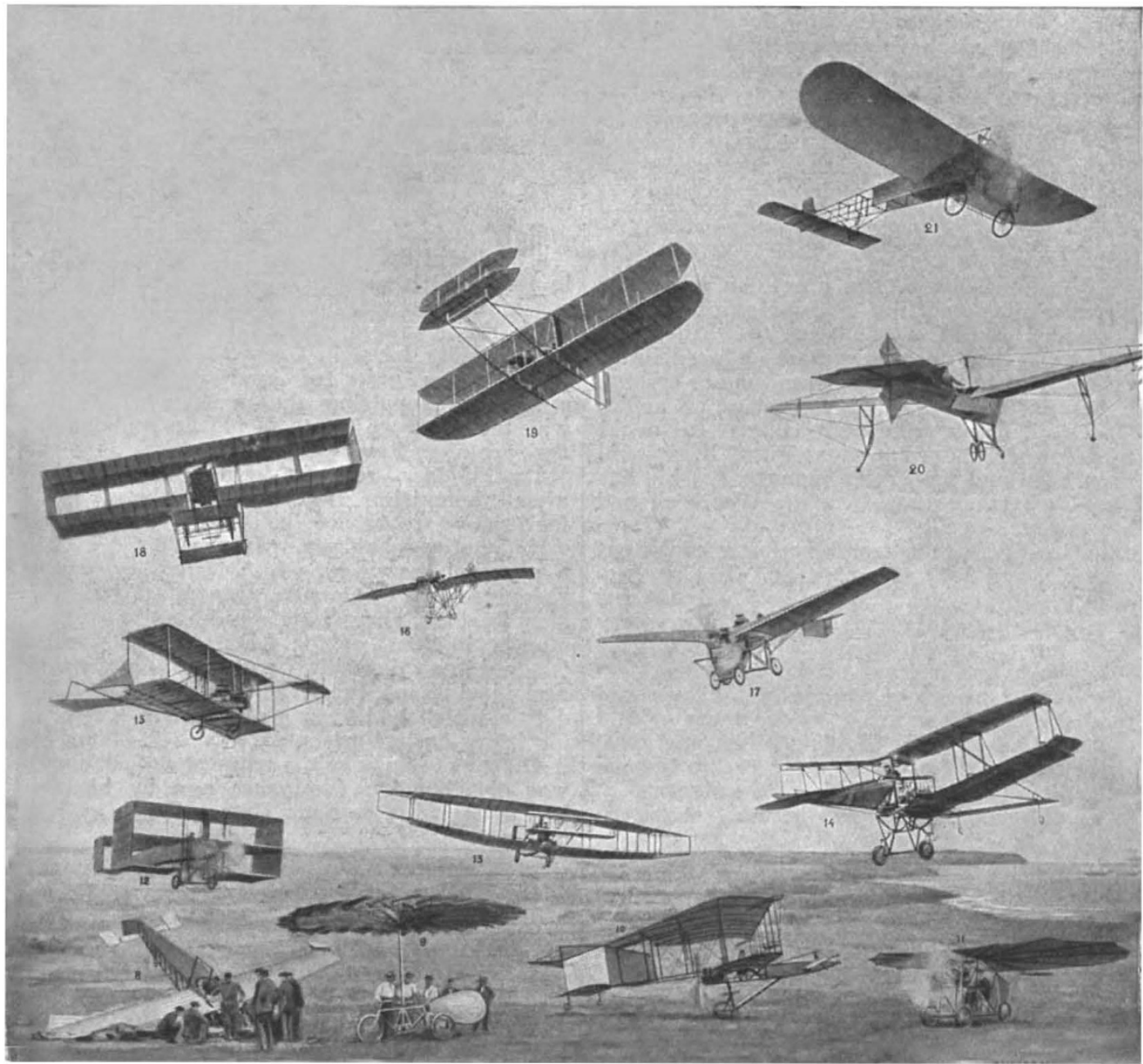

FIG. 2.-8. Blériot monoplane after accident. 9. Luyties American helicopter. ro. Bonnet Labrauche biplane. I1. Vuia helicopter. 12. Goupy triplane. 13. Curtiss's American biplane. I4. Zeus aëroplane. 15. Ferber biplane. I6. Santos Dumont's Demoiselle. 17. Gastambide Mangin biplane. 18. Farman's biplane which travelled from Bouy to Rheims (October 30, r9o8). 19. Wright's planes (xh. 7m. 35s.) and attempted to cross the Channel. 21. The Blériot XI., which crossed the Channel on July 25 , 1909.

in order to render them laterally stable, it seems somewhat rash to suggest that his fatal accident was due to the precautions being inadequate; yet it is just possible we may find that such was the case; if so, it is remarkable that Ferber should fail when others who have taken less adequate precautions have succeeded. Before his death Captain Ferber attributed the accident to flying too low, so that the machine struck the ground when it heeled over. Captain Ferber was the author of a number of papers and articles dealing with aviation, and also a keen balloonist.

NO. $208_{j}$, VOL. $\left.8 \mathrm{I}\right]$

G. H. B. from the Arsenal gates to the Woolwich Free Ferry is blocked by the refusal of official sanction.

(2) The same official sanction is withheld from all schemes for the authorised electric tramway from Woolwich to Eltham.

The facts we have been able to ascertain are as follows, premising that the Admiralty, and not the Astronomer Royal, is officially responsible for safeguarding the efficiency of the observatory records, and that the Board of Trade has to provide for adequate protection of the observatory for the magnetic portion of the work. 
(I) The proposal appears to have been brought up suddenly, without previous warning, towards the latter part of August, at a time when, as is well known, many Government officials are expected to be away on leave, and, consequently, delay is almost certain. It appears also that as soon as the question was gone into by those concerned, it was decided to consent to the proposal on the strict understanding that any further step in the conversion of the existing horsetramway between East Greenwich and Woolwich should be by extension of the conduit system eastwards, and not of the trolley system westwards. It is, of course, impossible to say how long it will be before this decision can have any practical effect, but it is certain that no further delay can be attributed to the observatory.

(2) As regards the authorised tramway from Woolwich to Eltham, we find that many Eltham residents are strongly opposed to the overhead system, while the official position is not one of hostility to the overhead system por se, but of insisting on insulated returns, any system which ensures this for the protection of Greenwich magnetic records being free from this official objection. As a case in point, the G.B. surface-contact system was proposed by the County Council several years ago and sanctioned officially, but was then dropped after some inconclusive experiments. Recently a new surface-contact system, the S.P. system, was made the subject of an article in Engineering, May 28, and claims to avoid the risk of danger alleged against the G.B. system. It has been tried and favourably reported on, but has not apparently been suggested for the Woolwich and Eltham tramway.

The official attitude thus seems perfectly consistent and reasonable, and not unsympathetic. The suggestion of overhead wires without insulated returns within a radius of three miles from the observatory ought once for all to be dropped. If the County Council objects to the expense of the conduit system and to the inconvenience of equipping the overhead system with insulated returns, it is for them to find a satisfactory alternative. Unless the protective clauses insisted on by the Government are to become a dead letter, it is futile to try to blame the observatory for delay or obstruction, and it is in the last degree unlikely that the Admiralty will be persuaded to stultify its own action and contention by allowing these clauses to be overridden.

\section{PETER BARR.}

$\mathrm{T}^{\mathrm{n}}$ EE name of this eminent horticulturist, whose death we announced last week, will ever be associated with the development of narcissi. Born in 1826 , in the former village of Govan, which has long since been absorbed in the city of Glasgow, he was the son of a mill-owner who found recreation from weaving in the cultivation of tulips and other florists' flowers. The son appears to have inherited a strong love for floriculture, for he soon tired of the looms, and obtained employment in various seed businesses, until in $\mathrm{r} 86 \mathrm{I}$ he commenced business, with a partner, on the site of the present premises of Messrs. Barr and Sons, King Street, Covent Garden, under the title of Barr and Sugden. Barr then directed his attention to practical floriculture, experimenting with hellebores (Christmas roses), tulips, lilies, and pæonies. For these purposes he found it necessary to take up a piece of ground at Tooting, where he conducted trials which interested the leading florists of the day. He next scoured the country over NO. 2083 , VOL. $8 \mathrm{I}]$ for narcissi, meeting with considerable success in his quest. Two amateurs had already formed wonderful collections of these flowers which, unknown to the general public, they had cultivated for nearly a quarter of a century. These were Mr. W. Backhouse, of Darlington, and Mr. Edward Leeds, of Manchester. Barr made up his mind that if he could only obtain possession of these collections he would have all the best of existing daffodils in his own possession. By dint of perseverance and enterprise he succeeded in this, and the collections were removed to Tooting, where for years afterwards new seedling varieties flowered every year. Every variety worth cultivating was named and its name registered, for he recognised that no commercial success would follow unless the public could be assured that every plant catalogued was accurately and intelligently named. But the varieties continued to multiply so greatly that he found it necessary to elaborate a classification, grouping the sorts into sections according to the length of the trumpet or perianth tube and other characteristics. Mainly owing to Barr's representations, the Royal Horticultural Society promoted a Daffodil Conference in $\mathrm{x} 884$, and his system of classification was then, in the main, adopted. Not long after this the attention of market growers was directed to these bulbs, and in the Scilly Isles, in Cornwall, in Lincolnshire, and other places acres of land were planted for the purpose of supplying the markets with cut blooms, with the result we see to-day in the millions of flowers that are offered everywhere for sale.

Peter Barr retired from business in 1896 , after botanising in various places in Europe for the purpose of collecting rare daffodils in their native habitats. In 1808 he began a tour round the world, which lasted seven years. He visited America, Canada, Japan, China, Australia, New Zealand, and, on his way home, spent twenty-one months in South Africa. During this world tour he lectured on daffodils, and was interviewed and acclaimed almost everywhere as the "Daffodil King," a title which had been given him in this country by his fellow-floriculturists.

One of the finest white trumpet daffodils ever raised was distributed a few years ago by his firm, and it was named after Peter Barr.

\section{NOTES.}

We learn from the Times, with deep regret, of the death, on Sunday last, of Prof. Anton Dohrn, the founder and director of the Zoological Station at Naples.

Sir Thomas Elliott, Secretary to the Board of Agriculture and Fisheries, has been nominated by the French Government to be a Companion of the Order "du Mérite Agricole."

In view of the retirement, to which reference has been made in these columns already, of Prof. J. Cleland, F.R.S., from the chair of anatomy, and of Prof. Jack from the chair of mathematics, at the end of the present month, there has been set on foot, on the initiative of the business committee of the general council of the University of Glasgow, a movement for making appropriate recognition of their long and distinguished services. Circulars have been issued to the whole body of university graduates and to members of other learned bodies with which Profs. Cleland and Jack have been connected. In the circulars it is stated that the form of recognition will, to a large extent, depend on the amounts subscribed, but it is thought that it might fitly include the provision of some fund for 